\title{
How PV systems can be cost-competitive for mobile BTS in remote areas of Algeria
}

\author{
Hamza Siyoucef ${ }^{1}$, Benameur Afif ${ }^{2}$, Amina Benhammou ${ }^{3}$, Boualem Merabet ${ }^{4, *}$ \\ 1,2,4 Department of Electrical Engineering, Fac. of Sciences/Technology, Mustapha Stambouli University, Mascara, \\ Algeria. \\ ${ }^{1}$ Laboratoire de Sciences et Techniques de l'Eau (LSTE) Université de Mascara, Algérie. \\ ${ }^{3}$ Department of Electrical Engineering, Saad DAhlab University, Boumerdes, Algeria.
}

\begin{tabular}{l}
\hline \hline Article Info \\
\hline Article history: \\
Received Jun 27, 2020 \\
Revised Mar 9, 2021 \\
Accepted Mar 22, 2021 \\
\hline Keyword: \\
Sustainable energy \\
PV systems \\
Third keyword \\
PVSYST \\
Telecom BTS \\
Hybrid-PV/Wind-Diesel \\
Battery
\end{tabular}

\begin{abstract}
Solar electricity for telecom infrastructure has became one of the main contributors of electrical energy to the energy system in the future, but solar technology needs support to find its way to the market. Since photovoltaic (PV) electricity always involves very high costs compared to electricity from other sources, a striking question is: how can PVs achieve competitiveness? There are different strategies for promoting applied PV electricity generation around the world. Here, we simulated and designed a $40 \mathrm{KWp}$ injected PV power, to evaluate the energy of the incident photon flux, produced by PV panels and that injected into the electricity grid, and then judge whether the installation is profitable and the technology chosen is economical. The results reveal that the site of Tamanrasset (extreme south of Algeria) could produce an annual energy production of $73863 \mathrm{kWh}$, justifying why the German Academy has chosen such site for the famous desert project, lastly launched between the two countries.
\end{abstract}

Copyright $(\odot) 2018$ Institute of Advanced Engineering and Science. All rights reserved.

\section{Corresponding Author:}

Boualem MERABET,

Department of Electrical and Computer Engineering,

Mustapha Stambouli University,

BP 763, Road of Mamounia, Mascara 29000, Algeria.

Email: b.merabet@univ-mascara.dz

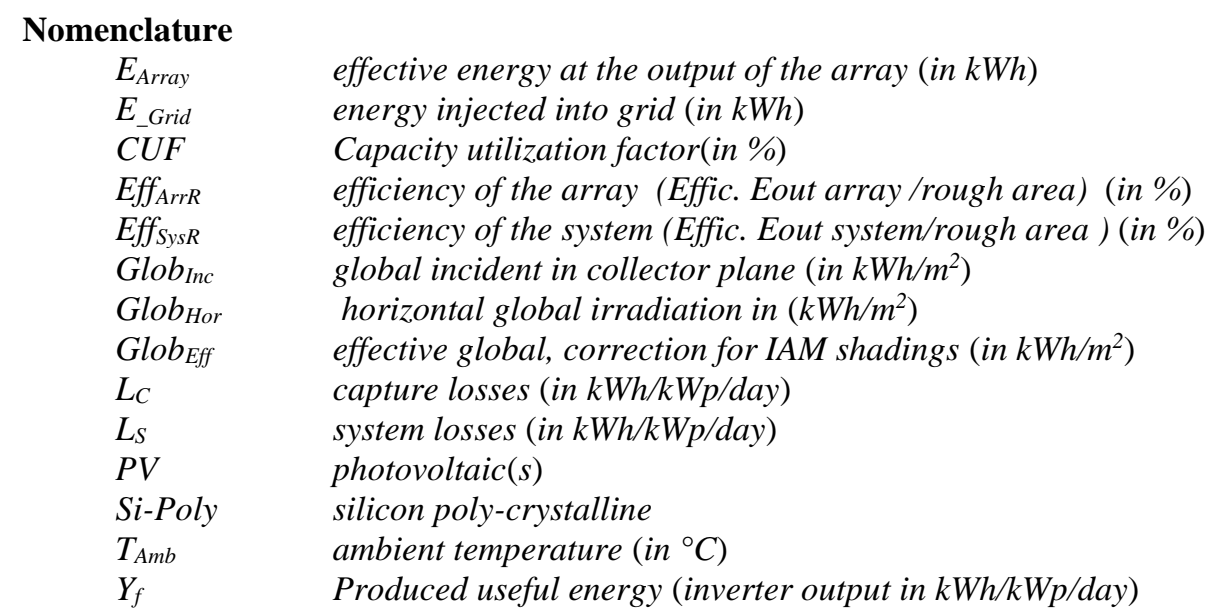

\section{INTRODUCTION}

Generating electric power uses mainly fossil and fissile fuels (FFs), and systematic use of these latter, such as oil, coal or natural gas allows for low production costs, and leads to a massive release of polluting gases 
and green-house gases [1]. $40 \%$ of global carbon (CO2) emissions originate from FF-based electricity generation, and nuclear energy, which does not emit directly from $\mathrm{CO} 2$, and generally suffers from a bad media image because of the significant risks involved [2]-[4]. Despite the fact risks of accidents related to their operation are very low, the consequences of an accident would be disastrous, and the treatment of waste from this production method is very costly [5],[6]. Even though many countries (like Algeria) have today surplus in electricity production, the future is not for FF resources, with reserves constantly diminishing and prices fluctuate enormously depending on the economic situation. In the field of information for example, telecom networks (TNs). have expanded to remote areas of the country (like peaks, forests and deserts) and demand for connectivity is growing. TNs are confronted with their non-existence in these regions and/or the instability of the power grids (their energy sources). Diesel generators, on which telecom companies have long relied in these regions, operate at a low level of efficiency, have become more expensive to operate and produce high $\mathrm{CO} 2$ emissions [7]. Moreover, climate changes today imminently threaten the prosperity that mankind enjoy, so as we should protect ecosystems and safeguard the biodiversity [8]. Hard efforts have been made in Algeria to optimize energy cost by converting indoor base transceiver station (BTS) into outdoor one to eliminate the use of air conditioner [9], installing energy efficient equipment [10] and the use of green energy sources to power telecom sites [11]. Also, the increased deployment of renewable energies (REs), especially solar photovoltaics (PV), that has reached historic levels, so as hydropower, biomass for power geothermal and onshore wind can all now provide electricity competitively compared to FF-fired power generation where good resources and cost structures exist [12-14]. Now, attributed renewable energy power capacity have record new additions that can be to rapidly falling costs and competitiveness, particularly for solar PV and wind power [15]. In this work, we aim to focus on the most competitive utility-scale solar PV projects in two (2) distinguished sites : Tamanrasset (blessed with abundant radiation with clear sky) in the Algerian south, and Tunis (north of Tunisia), in terms of ability and cost. Our goal here is to configure a PV-based system supplying BTS in order to avoid foreign tourists getting lost in the huge desert of Tamanrasset and help them enjoy their holydays. We have used PVsyst software [16], to determine systems behavior according to databases at different geographical sites, as well as technical parameters of different components.

A plethoria of works have been devoted to the performance and feasibility analysis of PV-based generation systems. For instance, V. Sharma et al. [17] carried out the performance analysis of a $190 \mathrm{kWp}$ solar PV power plant (Khatkar-Kalan, India) and found that the final yield, reference yield and performance ratio vary respectively in the ranges $1.45-2.84 \mathrm{kWh} / \mathrm{kWp}$-day, $2.29-3.53 \mathrm{kWh} / \mathrm{kWp}$-day and $55-83 \%$. Irwanto et al. [18] analysed the performance of PV output power, and reported an efficiency of PV under/without cooling system respectively to be $14 \%$ and $10.3 \%$, and an efficiency of PV module of $13.05 \%$ and $10.45 \%$ for incident irradiances of $1000 \mathrm{~W} / \mathrm{m} 2$ and $200 \mathrm{~W} / \mathrm{m} 2$, respectively. B. Shiva Kumar et al. [19] reported a final yield of the plant ranged from 1.96 to $5.07 \mathrm{~h} / \mathrm{d}$, and an annual performance ratio of $86.12 \%$, and that the plant has $17.68 \%$ CUF with annual energy generation of $15798.192 \mathrm{MWh} /$ Year. Allouhi et al. [20] carried out a performance analysis and economical/environmental assessment of two gridconnected PV systems (in Meknes, Morocco) and found a levelized cost of electricity (LCOE) and a payback time in the ranges $0.073-0.082 \$ / \mathrm{kWh}$ and10 12.69 years, respectively. Malvoni et al. [21] investigated the performance of a $960 \mathrm{kWP}$ PV system (southern Italy), and reported that the performance ratio, capacity factor, yearly average module efficiency, system efficiency, capture and system losses were found to be $84.4 \%, 15.6 \%, 15.3 \%, 14.9 \%$, and $0.6 \mathrm{~h} / \mathrm{day}$ and 0.1 $\mathrm{h}$ /day, respectively. Pillai et al. [22] studied a 1MW PV grid connected system (in Bahrain) and reported an LCOE of $0.0423 \$ / \mathrm{kWh}(16 \mathrm{fils} / \mathrm{kWh}$ ) that is $43 \%$ less than the present actual cost of a $\mathrm{kWh}$ of generation. M. R. Akhtari et al. [23] adopted an innovative method to recover surplus electricity to generate heat and cut emissions, and reported that recovering extra electricity enhance renewable fraction by up to $35 \%$ and bring down cost of energy and exhausted CO2 by 7.1 and $10.6 \%$, respectively. Thotakura et al. [24] presented the performance of a megawatt-scale grid-connected rooftop solar photovoltaic (PV) plant installed on the building rooftops of an educational institute (Andhra Pradesh, India), reported a solar PV plant supplied energy of 1325.42 MWh to the grid during the monitored period, an average mean bias error of $30.64 \%$, and average normalized mean bias error of $22.75 \%$. Goel et al. [25] carried out a performance of a $11.2 \mathrm{kWp}$ grid-connected rooftop solar PV system (in Bhubaneswar, India), and found an annual energy with Meteonorm-derived data of $9.2 \%$ and $14.75 \%$ higher than the measured value.

PVSyst software used here offers three PV system levels, corresponding to different stages of developing a real project. The rest of the paper is organised as follows: Section 2 lists the research method used to evaluate the performance of system, which is available for supplying TNs, as found in the literature. Particular emphasis is given to the assessment that is found to be used in reality at a great extent as a convenient approach. In Section 3 one of the main alternative solutions to feed mobile BTS in remote areas is discussed with special focus on the impact of PV system sizing fed into the grid, production evaluation of the system when injected into-grid energy, and economic estimation. Section 4 concludes the paper. 


\section{RESEARCH METHOD}

In this part, we aim at identifying the tool on which our investigation is based, and assessing data to analyze the performance of the system that will feed mobile BTS in remote areas. The system designed to feed a BTS in Tamanrasset area consists of a PV based RE as a power source, where PVsyst coordinates, measures and accesses a PV-based system. Once area and load are characterized, BTS technicians may choose constituents from an item database to compute the measure for each constituent.

\subsection{PVSYSTEM Software}

The performance of our system is based on a simulation studied by PVSYST, that establishes an overall performance of the standalone PV system and generates the resources data for the whole year. The output of our system is discussed via simulation tools like the potential energy resources, component sizing, energy production from a standalone PV system, and system losses. Global radiation and temperature are keyparameters to ensure running simulation, so that the installation solar benefits depend strongly on the yearly sunlight intensity. The simulated model, technically sized as per the project specifications, using PVsyst simulation tool, consists of PV modules, inverters and grid interface network [16].

\subsection{Assessment and Analysis}

The ideal location of Tamanrasset (As shown in Fig. 1) exhibit a highest annual global solar radiation (Fig. 2) of $270 \mathrm{~W} / \mathrm{m}^{2}$, followed by Tunis: $206.4 \mathrm{~W} / \mathrm{m}^{2}$. Tamanrasset coordinates are $22^{\circ} 47^{\prime} 20^{\prime \prime} \mathrm{N}$ and $5^{\circ} 31^{\prime} 32^{\prime \prime} \mathrm{E}$, It is located at an altitude of $1.320 \mathrm{~m}$, where very high temperatures of over $47^{\circ} \mathrm{C}$ have been recorded. The inclination angles of the panels necessary for sun to fall on the periods of time and consequently give optimal field production, allowing us to take maximum advantages of the sunlight during the day. Here, a comparative performance study of grid tied PV-based systems in Tamarasset and Tunis sites using PVsyst is presented. The inclination angles of the inclined planes of the two sites are set at $23^{\circ}$ and $30^{\circ}$, respectively.

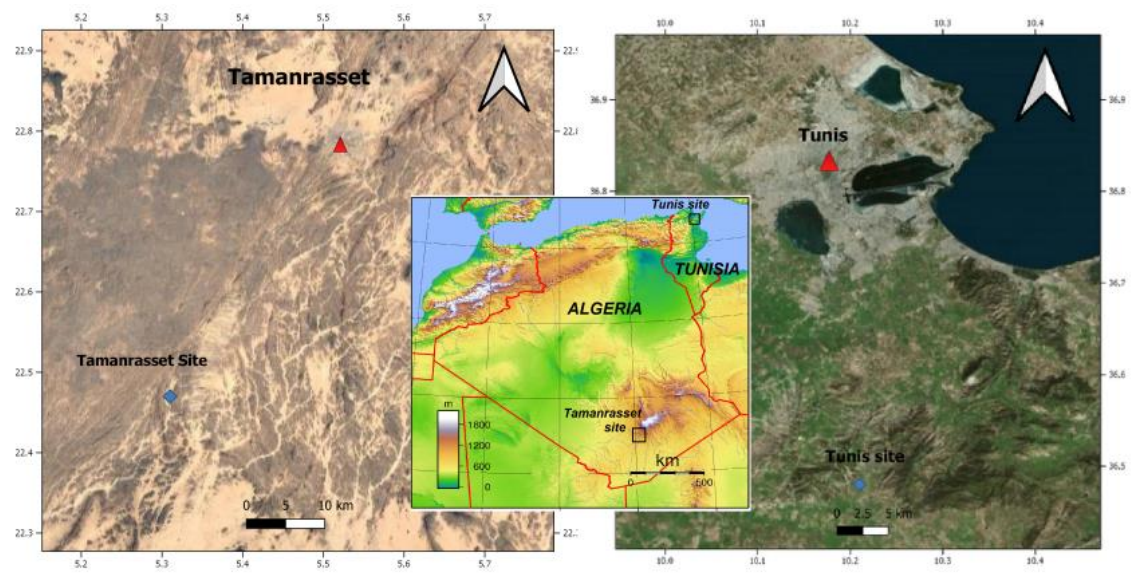

Figure 1. Site Locations of Tamanrasset and Tunis.

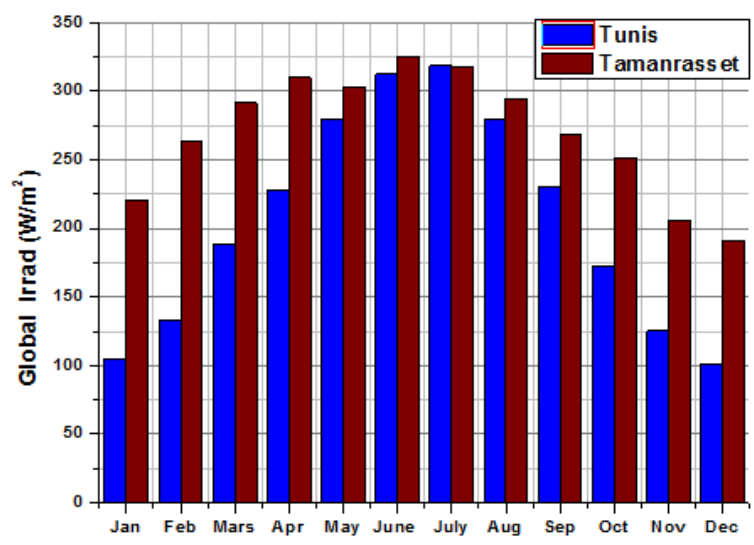

Figure 2. Annual global solar radiation in both areas.

Since both countries are in the northern hemisphere, a best mode to direct PV panels is to the south because solar cells are to be facing the path of sun, to obtain a highest solar radiation and much better power production of PV panels. 


\section{RESULTS AND ANALYSIS}

The studied system involves mobile BTS in remote areas from six countries (mainly two among these for comparision), and focuses on managing electricity supply/demand, and integrating decentralized energy resources in TNs. Using PVSyst, at variance to sizing apparatus, components' kind and size are stated. It supplies an illustrative analysis of the system, picks loads and solar power data, and models PV and electrical components of various sizes to correspond a request.

\subsection{PV system Sizing fed into the grid}

The PV system sizing, taking into account the technical parameters of the modules and converter, is shown in Fig. 3. As mentioned above, a PV generator fed into the grid has been considered, without batteries, to supply a village of 20 households, each household has a daily consumption of $2 \mathrm{KWh}$; therefore the overall power is estimated at $40 \mathrm{KWh}$. For this purpose the 29V/220W modules in Si-poly PV system, brand Zhejiang Wanxiang WXS220S, 3KW power converter with $50 \mathrm{~Hz}$ frequency at a voltage range of 125 to $600 \mathrm{~V}$, and a brand SMA referenced Sunny Boy SB 3300 TL HC, have been chosen. Such parameters are considered constant for both sites: the same power, modules, and energy converters. Beside grid lines, fuse box and utility meter, the main elements used to configure this grid-connected PV system are inverters and PV modules. These produce DC power (current and voltages) and the inverter assures the DC-to-AC convertion. The AC inverter has outputs supplied to grid boosted by an utility meter and a fuse box. An inverter (in grid connected PV systems) operates in phase with the grid, and continuously produces a sinusoidal output. As for the grid connection, it can be made from output terminals of the inverter with the connection of an utility meter and a circuit breaker in fuse box. [26]

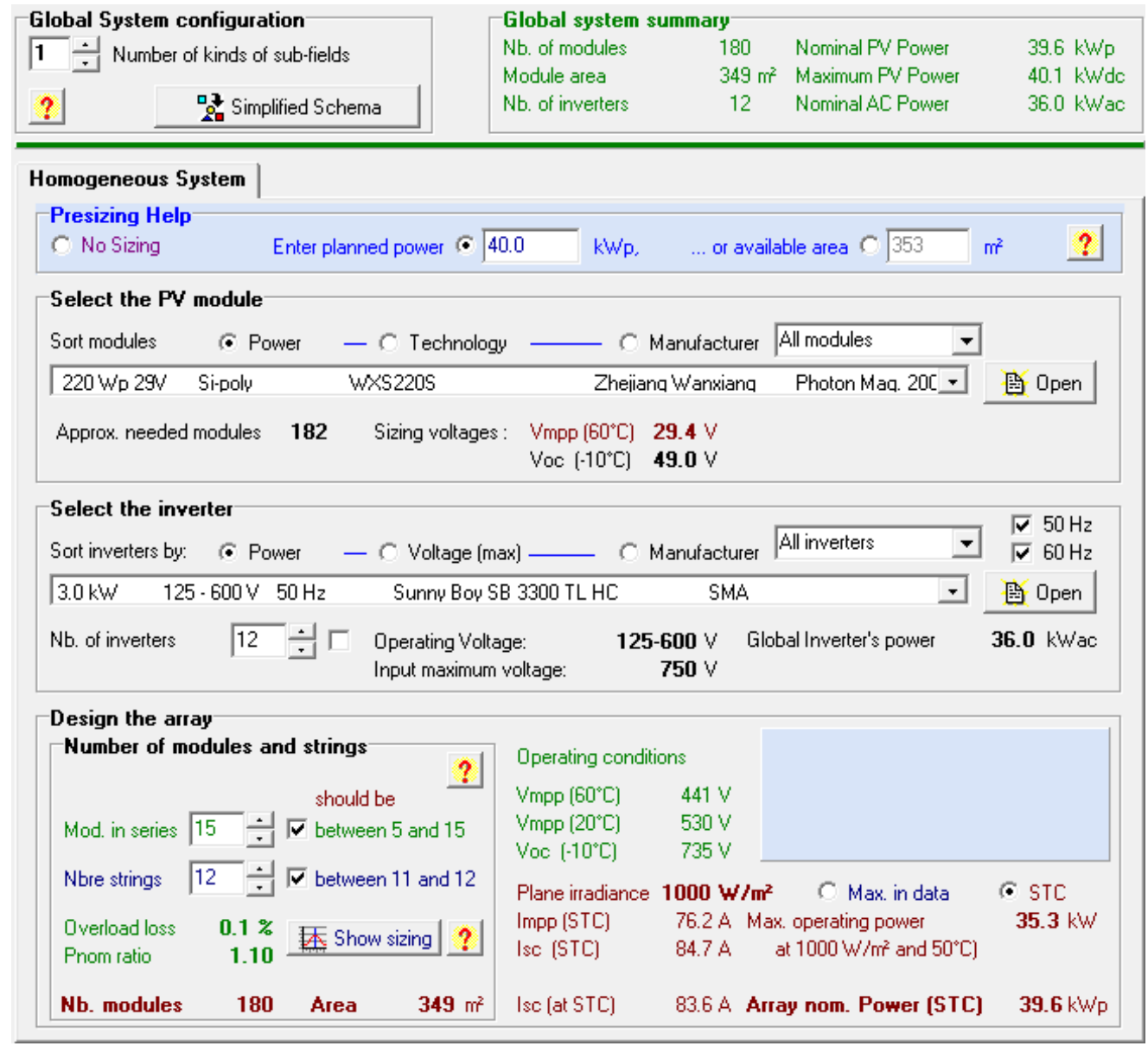

Figure 3. Dimensioning grid-connected PV systems for both sites.

\subsection{Production Evaluation of the system when injected into the grid}

In Table 1 (summarizing results shown below), the highest annual global solar radiation and power parameters are recorded. DC power provided by Si-poly PV arrays, injected into-grid energy the considering

How PV systems can be cost-competitive for mobile BTS in remote areas of Algeria (Hamza Siyoucef et al) 
losses in electrical components, PV arrays and system efficiency are also calculated here. All computed values mentioned in balances and main results were monthly and yearly obtained (temperature averages, efficiency and summation for irradiance and energy are given in average values). As shown in the summary analysis results illustrated by Table 1, a highest annual production of $73863 \mathrm{kWh}$ was recorded in Tamanrasset, with a contribution of $7042 \mathrm{kWh}$ given in March. We also note that the solar radiation in July is the highest at 236 $\mathrm{kWh} / \mathrm{m}^{2}$ compared to that of $217 \mathrm{kWh} / \mathrm{m}^{2}$ in March, while the temperatures are respectively 28.40 and $17.40^{\circ} \mathrm{C}$, which influences the decrease in panel production and the higher collection and system losses at temperatures above $25^{\circ} \mathrm{C}$.

Table 1. Summary of monthly and annual results (Balances and main results of $39.6 \mathrm{kWp} \mathrm{Si-poly} \mathrm{PV}$ systems) obtained for both sites: Tamanrasset (in blue) and Tunis (in red).

\begin{tabular}{ccccccccc}
\hline & $\begin{array}{c}\text { GlobHor } \\
\left(\mathrm{kWh} / \mathrm{m}^{2}\right)\end{array}$ & $\begin{array}{c}T_{\text {Amb }} \\
\left({ }^{\circ} \mathrm{C}\right)\end{array}$ & $\begin{array}{c}\text { Glob }{ }_{\text {Inc }} \\
\left(\mathrm{kWh} / \mathrm{m}^{2}\right)\end{array}$ & $\begin{array}{c}\text { GlobEff } \\
\left(\mathrm{kWh} / \mathrm{m}^{2}\right)\end{array}$ & $\begin{array}{c}E_{\text {Array }} \\
(\mathrm{kWh})\end{array}$ & $\begin{array}{c}\text { E_Grid } \\
(\mathrm{kWh})\end{array}$ & $\begin{array}{c}\text { EffArrR } \\
(\%)\end{array}$ & $\begin{array}{c}\text { EffSysR } \\
(\%)\end{array}$ \\
\hline January & $164 / 78$ & $11.8 / 13.5$ & $219.7 / 117.3$ & $214.1 / 114.1$ & $7052 / 3881$ & $6721 / 3695$ & $9.19 / 9.47$ & $8.76 / 9.02$ \\
February & $177 / 89$ & $13.8 / 13.3$ & $217.8 / 119.1$ & $212.3 / 115.6$ & $6799 / 3872$ & $6479 / 3672$ & $8.94 / 9.318 .52 / 8.83$ \\
March & $217 / 140$ & $17.4 / 13.1$ & $238.2 / 168.2$ & $231.9 / 163.6$ & $7387 / 5449$ & $7035 / 5184$ & $8.88 / 9.27$ & $8.46 / 8.82$ \\
April & $223 / 164$ & $21.8 / 14.7$ & $219.3 / 171.3$ & $212.9 / 166.1$ & $6685 / 5521$ & $6369 / 5249$ & $8.73 / 9.23$ & $8.32 / 8.77$ \\
May & $225 / 208$ & $25.4 / 18.2$ & $204.5 / 198.3$ & $198.1 / 192.3$ & $6192 / 6263$ & $5895 / 5956$ & $8.67 / 9.04$ & $8.25 / 8.60$ \\
June & $234 / 225$ & $28.1 / 21.7$ & $203.5 / 204.3$ & $196.7 / 197.7$ & $6047 / 6297$ & $5758 / 5990$ & $8.51 / 8.82$ & $8.10 / 8.39$ \\
July & $236 / 237$ & $28.4 / 25.3$ & $209.7 / 220.0$ & $202.6 / 212.9$ & $6218 / 6586$ & $5921 / 6263$ & $8.49 / 8.57$ & $8.08 / 8.15$ \\
August & $219 / 208$ & $27.9 / 26.5$ & $208.3 / 210.3$ & $202.0 / 204.1$ & $6213 / 6341$ & $5919 / 6038$ & $8.54 / 8.63$ & $8.13 / 8.22$ \\
September & $193 / 166$ & $25.9 / 26.5$ & $201.9 / 190.0$ & $196.4 / 184.6$ & $6098 / 5754$ & $5818 / 5478$ & $8.65 / 8.67$ & $8.25 / 8.25$ \\
October & $187 / 128$ & $22.3 / 21.9$ & $218.6 / 168.9$ & $213.1 / 164.4$ & $6714 / 5296$ & $6406 / 5047$ & $8.79 / 8.98$ & $8.39 / 8.56$ \\
November & $148 / 90$ & $18.2 / 17.7$ & $188.8 / 137.1$ & $183.7 / 133.1$ & $5909 / 4401$ & $5634 / 4192$ & $8.96 / 9.19$ & $8.55 / 8.76$ \\
December & $142 / 75$ & $13.8 / 14.80$ & $192.7 / 121.8$ & $187.4 / 118.4$ & $6198 / 3999$ & $5909 / 3808$ & $9.21 / 9.41$ & $8.78 / 8.95$ \\
\hline \multicolumn{2}{c}{ Year } & $2365 / 1808$ & $21.27 / 18.89$ & $2522.9 / 2026.5$ & $2451.2 / 1966.9$ & $77511 / 63661$ & $73863 / 60571$ & $8.80 / 8.998 .38 / 8.56$ \\
\hline
\end{tabular}

\subsection{Normalized productions}

Collection losses, system losses and produced useful energy per installed $\mathrm{kWp} /$ day (normalized productions) were evaluated from the simulations, as can be seen in Fig. 4. Defined by the IEC norms [27] such normalized productions are standardized variables to acurately assess the PV system performance. The Collection losses (PV array capture losses), system loss, and produced useful energy ( $\mathrm{L}_{\mathrm{c}}, \mathrm{Ls}_{\mathrm{s}}$ and $\mathrm{Y}_{\mathrm{f}}$ ) are respectively $1.15 \mathrm{kWh} / \mathrm{kWp} /$ day, $0.21 \mathrm{kWh} / \mathrm{kWp} /$ day and $4.19 \mathrm{kWh} / \mathrm{kWp} /$ day for Tamanrasset, and 1.55 $\mathrm{kWh} / \mathrm{kWp} /$ day, $0.25 \mathrm{kWh} / \mathrm{kWp} /$ day and $5.11 \mathrm{kWh} / \mathrm{kWp} /$ day for Tunis, comparable to those of [28] (for an educational institute, India) found to be $1.0 \mathrm{kWh} / \mathrm{kWp} /$ day, $0.1 \mathrm{kWh} / \mathrm{kWp} /$ day and $4.42 \mathrm{kWh} / \mathrm{kWp} / \mathrm{day}$, respectively.

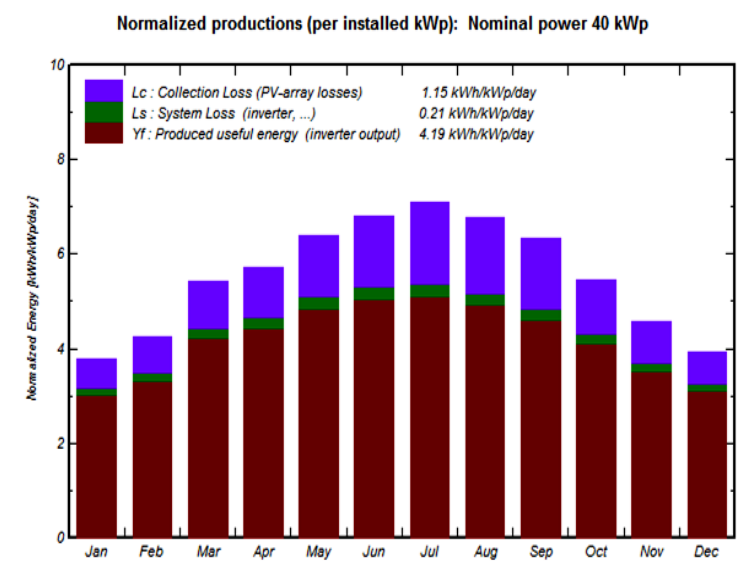

(a)

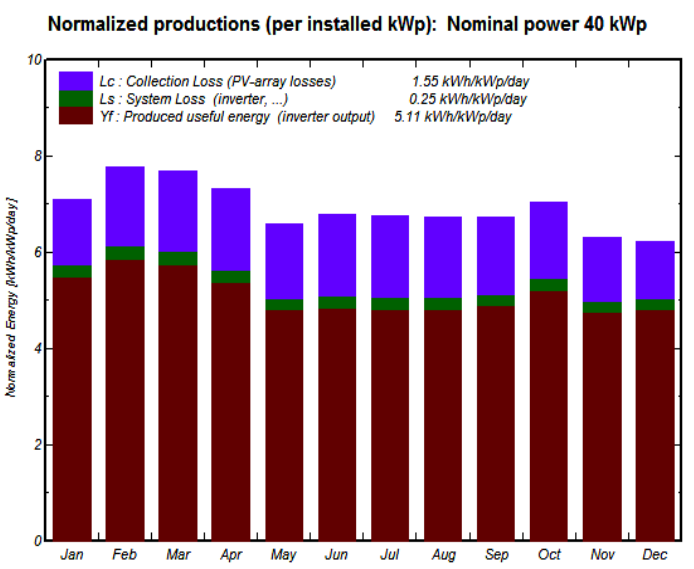

(b)

Fig. 4. Normalized energy productions per installed kWp, in: a) Tamanrasset, b) Tunis. 


\subsection{Economic evaluation}

The costs of a solar PV system depends on several factors. Based on the international PV market, and to standardize the results, we have based ourselves on European prices, as long as the Algerian market is neither matured in this field nor administered yet, so Tunisia and Morocco follow Europe. As a result, It has found that the overall price of our system which will be the same for all the sites considered, so that we can evaluate the return on investment for each site following its production. The mean obtained results are so that system productions, normalized productions, producible, Fields losses, performance indexes, and system losses are respectively in:

- Tamanrasset: $73863 \mathrm{kWh} /$ year, $5.11 \mathrm{kWh} / \mathrm{kWc} /$ day, $1866 \mathrm{kWh} / \mathrm{kWc} / \mathrm{year}, 1.55 \mathrm{kWh} / \mathrm{kWc} / \mathrm{day}, 0.739$, and $0.25 \mathrm{kWh} / \mathrm{kWc} / \mathrm{day}$.

- Tunis: $60571 \mathrm{kWh} / \mathrm{year}, 4.20 \mathrm{kWh} / \mathrm{kWc} /$ day, $1533 \mathrm{kWh} / \mathrm{kWc} / \mathrm{year}, 1.14 \mathrm{kWh} / \mathrm{kWc} / \mathrm{day}, 0.756$, and 0.21 $\mathrm{kWh} / \mathrm{kWc} / \mathrm{day}$.

According to the results obtained from an economic evaluation of our system connected to the grid, we notice that the overall net investment does not have too different values except in the case of Algiers and Tamanrasset, which is reflected in the products imported from Europe, and also the working conditions in the south. Then, and following the same economic evaluation and considering the annual production of the system and the return of inversion over 20 years, it was deduced that the cost of the energy produced is the same value of 0.16 for Perpignan and Algiers, also the same value for Tunis and Casablanca of $0.14 € / \mathrm{kWh}$, the maximum cost price per $\mathrm{kWh}$ is that of Frankfurt at $0.23 € / \mathrm{kWh}$, while the minimum value is that of $0.12 € / \mathrm{kWh}$ reached for Tamanrasset.

The analysis of the long-term financial balance sheet (Fig. 5) revealed that our system is not profitable in Frankfurt site or a similar weather data site, because we notice that we can sell energy, but the gain amortize the amount of the project. As for Algiers site, our system can give a positive gain in only 15 years, while in Casablanca the return on profitable in the Frankfurt site or a similar weather data site, because we notice that we can sell energy, but the gain investment is only 11 years. An installation in Tunis is profitable after five (5) years, while the most fabulous is the Tamanrasset site, which has made a perfect profit since the first day of operation. For this analysis, we considered the sales rates in Europe, Tunisia, and Morocco which are equal to $13.75 €$. An accurate analysis reveals how the cost of the energy used about $0.14 € / \mathrm{kWh}$ is low. As the annual connexion tax costs $250 €$ with a warranty over 20 years.

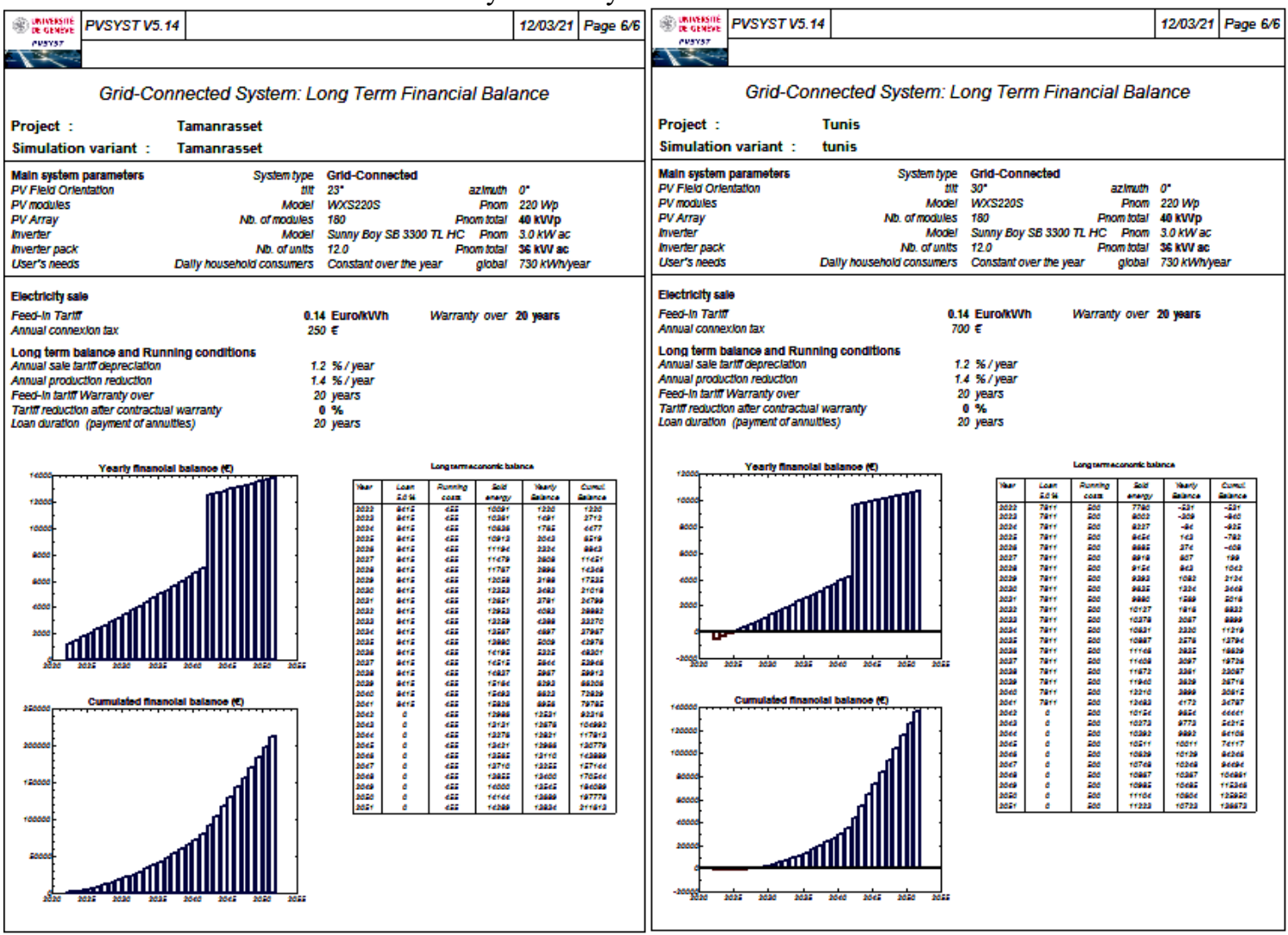

(a)

(b) 
Fig. 5. Economic evaluation (financial report) of the system in: $a$ ) Tamanrasset, $b$ ) Tunis.

This techno-economic analysis of PV-based power supply system for a remote telecom mobile base station could be of a great interest. For TNs, a PV system is an alternative for conventional standalone diesel configuration not economically feasible due to the high cost of diesel. Such choice should have significant effect on the operating cost of the mobile telecom operation and also environmental impact due to high $\mathrm{CO} 2$ emissions from the system. As a perspective, we aim configure a PV/Wind hybrid system to supply a BTS to help tourists enjoy their holydays and avoid them getting lost in the huge areas of Tamanrasset.

\section{CONCLUSION}

Simulated performance of $39.6 \mathrm{kWp}$ grid connected Si-poly PV system is performed using PVsyst software (as a simulation tool). The energy production varies in Tamanrasset regarding to the power, quality of PV module and energy converters: that is why the German Academy chosen such site for the launched famous desert project. From this simulation and by comparing between Tamarasset and Tunis sites, these points should be noticed:

- Annually, 73.86 MWh/year is the injected into-grid energy in Tamarasset site with specific production on annual basis per installed $\mathrm{kWp}$ is $1866 \mathrm{kWh} / \mathrm{kWp} / \mathrm{year}$.

- A maximum of injected into-grid energy in such site found to be $7387 \mathrm{kWh}$ was mentioned in March, and a minimum energy of $5909 \mathrm{kWh}$ was noticed in November.

- The planned PV system should provide operational benefits to installed BTS of TNs in Tamanrasset, and such study can be performend by the use of different PV module technologies with appropriate installation methods for improving performances. Finally, PV based-REs for TNs can be competitive and may even save consumers money today and in the future.

\section{REFERENCES}

[1] S. Taylor Chowdhury, S. P. Chowdhury, A. K. Saha and Y. H. Song, Modelling. simulation and performance analysis of a PV array in an embedded environment, 42nd International Universities Power Engineering Conference 2007; Brighton 781-785. doi: 10.1109/UPEC.2007.4469048

[2] H. Beltra, E. Bilbao, E. Belenguer, I. Etxeberria-Otadui et al., Evaluation of Storage Energy Requirements for Constant Production in PV Power Plants. IEEE Transactions on Industrial Electronics 2013; 60 (3) 1225-1234. doi: 10.1109/TIE.2012.2202353

[3] T. MA, H. Yang and L. Lu, Solar photovoltaic system modeling and performance prediction. Renewable and Sustainable Energy Reviews 2014; 36 304-315. doi.org/10.1016/j.rser.2014.04.057

[4] M.S. Haitham Bahaidarah, Experimental performance evaluation and modeling of jet impingement cooling for thermal management of photovoltaics, Solar Energy Volume 2016; 135 605-617. doi.org/10.1016/j.solener.2016.06.015

[5] T. Adefarati, R. C. Bansal, Reliability assessment of distribution system with the integration of renewable distributed generation, Applied Energy 2017; 185(1) 158-171. doi.org/10.1016/j.apenergy.2016.10.087

[6] Yushchenko A, Bono A , Chatenoux B , Kumar M, Ray P N, GIS-based assessment of photovoltaic (PV) and concentrated solar power (CSP) generation potential in West Africa. Renewable and Sustainable Energy Reviews 2018; 81(2) 2088-2103. doi.org/10.1016/j.rser.2017.06.021

[7] K. Siraganyan, A. D. Perera, J-L. Scartezzin, D. Mauree, Eco-Sim: A Parametric Tool to Evaluate the Environmental and Economic Feasibility of Decentralized Energy Systems, Energies 2019; 12 776. doi.org/10.3390/en12050776

[8] E. Moe, Does politics matter? Explaining swings in wind power installations, AIMS Energy 2017; 5 (3), 341373. doi.org/10.3934/energy.2017.3.341.

[9] S. N. Roy, " Energy logic: A road map to reducing energy consumption in telecommunications networks," in INTELEC; 2008 IEEE 30th International Telecommunications Energy Conference, San Diego, CA, 2008; 1-9. doi. 10.1109/INTLEC.2008.4664025

[10] G. Koutitas, and P. Demestichas, Challenges for Energy Efficiency in Local and Regional Data Centers. Journal of Green $\quad$ Engineering; 2010 1-32. River Publishers.

[11] S. Hashimoto, et al., " A new stand-alone hybrid power system with wind generator and photovoltaic modules for a radio base station," INTELEC 2004. 26th Annual International Telecommunications Energy Conference, Chicago, IL, USA, 2004, 254-259. doi: 10.1109/INTLEC.2004.1401475

[12] T. Ackermann, T. Prevost, V. Vittal, A. J. Roscoe, J. Matevosyan and N. Miller, "Paving the Way: A Future Without Inertia Is Closer Than You Think," in IEEE Power and Energy Magazin 2017; 15 (6) 61-69. doi: 10.1109/MPE.2017.2729138

[13] D. Gielen, F. Boshell, D. Saygin, M. D. Bazilian, N.Wagner, R.Gorini, The role of renewable energy in the global energy transformation. Energy Strategy Reviews 2019; 24 38-50. doi.org/10.1016/j.esr.2019.01.006

[14] C. Clauser and M. Ewert, The renewables cost challenge: Levelized cost of geothermal electric energy compared to other sources of primary energy - Review and case study, Renewable and Sustainable Energy Reviews 2018; 82 (3) 3683-3693. doi.org/10.1016/j.rser.2017.10.095 
[15] Mcelroy M B and Chen X, Wind and solar power in the united states: status and prospects, in CSEE Journal of Power and Energy Systems, 2017; 3 (1) 1-6. doi: 10.17775/CSEEJPES.2017.0002

[16] https://www.pvsyst.com/help (PVsyst 6 Help Doc).

[17] Vikrant Sharma, S.S. Chandel, Performance analysis of a $190 \mathrm{kWp}$ grid interactive solar photovoltaic power plant in India, Energy 55 (2013) 476-485.

[18] M. Irwanto, Y. M. Irwan, I. Safwati, W. Leow and N. Gomesh, "Analysis simulation of the photovoltaic output performance," 2014 IEEE 8th International Power Engineering and Optimization Conference (PEOCO2014), Langkawi, Malaysia, 2014, pp. 477-481, doi: 10.1109/PEOCO.2014.6814476.

[19] [B. Shiva Kumar, K. Sudhakar, Performance evaluation of $10 \mathrm{MW}$ grid connected solar photovoltaic power plant in India, Energy Reports 1 (2015) 184-192.

[20] Allouhi, A., Saadani, R., Kousksou, T., Saidur, R., Jamil, A., \& Rahmoune, M. (2016). Grid-connected PV systems installed on institutional buildings: Technology comparison, energy analysis and economic performance. Energy and Buildings, 130, 188-201. doi:10.1016/j.enbuild.2016.08.054.

[21] M. Malvoni, A. Leggieri, G. Maggiotto, P.M. Congedo, M.G. De Giorgi Corrigendum To Long Term Performance, Losses And Efficiency Analysis Of A 960 Kwp Photovoltaic System In The Mediterranean Climate [Energy Conversion And Management 145 (2017) 169-181] Energy Conversion and Management, Volume 159, 1 March 2018, Pages 413.

[22] G. Pillai, H. A. Yaqoob Naser, Techno-economic potential of largescale photovoltaics in Bahrain, Sustainable Energy Technologies and Assessments 27 (2018) 40-45.

[23] M. R. Akhtari, M. Baneshi, Techno-economic assessment and optimization of a hybrid renewable cosupply of electricity, heat and hydrogen system to enhance performance by recovering excess electricity for a large energy consumer, Energy Conversion and Management 188 (2019) 131-141.

[24] S.Thotakura, S. Chandan Kondamudi, J. F. Xavier, M. Quanjin, G. R. Reddy, P. Gangwar, S. L. Davuluri, (2020). Operational performance of megawatt-scale grid integrated rooftop solar PV system in tropical wet and dry climates of India. Case Studies in Thermal Engineering, 100602. doi:10.1016/j.csite.2020.100602.

[25] S. Goel, R. Sharma, Analysis of measured and simulated performance of a grid-connected PV system in eastern India, Environment, Development and Sustainability (2021) 23:451-476. doi.org/10.1007/s10668-020-00591-7.

[26] Mohamed A. Eltawil, Zhengming Zhao, Renewable and Sustainable Energy Reviews 2010; 14: 112-129.

[27] IEC. Photovoltaic System Performance Monitoring-Guidelines for Measurement Data Exchange and Analysis. IEC Standard 61724. Geneva Switzerland; 1998.

[28] Nallapaneni Manoj Kumar, M. Rohit Kumar, P. Ruth Rejoice, Mobi Mathew, Energy Procedia 117 (2017) 180-189.

\section{BIOGRAPHY OF THE CORRESPONDING AUTHOR}

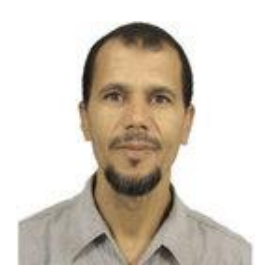

B. Merabet was born in Algeria. He received the B.Sc. degree from the University of Oran, Algeria, in 1989, and Magister/Ph.D. degrees from the Djillali Liabes University of Sidi BelAbbes, Algeria, in 2009 and 2012. First, He was a Professor of physics and electrical engineering at secondary school from 1989 to 2013. Now, he is a Professor of electrical engineering at Mustapha Stambouli University of Mascara, Algeria. He is involved in national research prjects and university trainings. He has published numerous papers on materials science, optoelectronics, and telecom networks. Professor Merabet is an active researcher and coworker of CLHYO lab (Italy) and "ileri-teknoloji-egitim-arastirma-ve-uygulama-merkezi" research center (Turkey). He is the head of doctoral training in Optical telecoms since 2018 and a Supervisor of PhD students. He is a peer reviewer of Elsevier journals, an editorial member of international journals, and a member of scientific program committees of IEEE conferences. 